Proceedings

\title{
Paving the Road for Sustainability through Global Understanding of Heritage ${ }^{\dagger}$
}

\author{
Luiz Oosterbeek ${ }^{1, *}$, Maria H. Henriques ${ }^{2}$, Pierluigi Rosina ${ }^{1}$ and Luís M. Figueira ${ }^{1}$ \\ 1 Instituto Politécnico de Tomar, Instituto Terra e Memória, Centro de Geociências da Universidade de \\ Coimbra, Estrada da Serra, 2300-313 Tomar, Portugal; prosina@ipt.pt (P.R.); lmota@ipt.pt (L.M.F.) \\ 2 Centro de Geociências da Universidade de Coimbra, Pólo II, Rua Sílvio Lima, 3030-790 Coimbra, Portugal; \\ hhenriq@dct.uc.pt \\ * Correspondence: loost@ipt.pt; Tel.: +351-917-849-330 \\ + Presented at the 1st International Electronic Conference on Geosciences (IECG 2018), 15-30 June 2018; \\ Available online: https://sciforum.net/conference/IECG_2018.
}

Published: 15 June 2018

\begin{abstract}
The contemporary understanding that heritage comprises the whole bio and geosphere, due to the direct or indirect anthropic impact all over the planet, allows for a global understanding of heritage that pervades all domains of sustainability research. The current debate on the so-called Anthropocene calls for revisiting past strategies of humans-environment disruptive episodes, in order to better understand the global implications of everyday actions and the wider implications of the interactions between technology and sociocultural structure. This paper discusses how low demographic density territories may offer the best examples of integrated responses, engaging geosciences as a backbone for interaction with tourism, technology, or societal strategies.
\end{abstract}

Keywords: heritage; anthropogenic processes; global understanding; sustainability

\section{Introduction}

The contemporary understanding that heritage comprises the whole bio and geosphere, due to its direct or indirect anthropic impact all over the planet, allows for a global understanding of heritage that pervades all domains of sustainability research [1].

The traditional dichotomy between "natural" and "cultural" heritage has been continuously challenged by a combination of three factors: an awareness that the perception of territories is always culturally framed, natural landscapes being a cultural perception themselves, which relates to the artificial segregation of the human from the wild; the recognition that not only the whole planet has been anthropized through contamination features (radiations, residues, etc.) but that even alleged "natural" features such as the Amazonian rain forest have been manipulated by human agents for centuries or millennia; the great acceleration processes and the resulting understanding of the integration of all variables and drivers, rendering useless the mentioned dichotomy [2].

An integrated approach to sustainability, increasingly understood through international conventions, despite its advances (namely, the recognition of human agency, in title of the final document of the Rio +20 summit) [3], remains largely caught by the epistemological mistake of the original concept of sustainability, segregating economy from society and largely ignoring the cultural variables for agency [4].

Nevertheless, the current debate on the so-called Anthropocene calls for revisiting past strategies of humans-environment disruptive episodes, in order to better understand the global implications of everyday actions and the wider implications of the interactions between technology and sociocultural structure. Anthropogenic evidence is the core of heritage, and its assessment allows tracing processes in terms of landscape management, illustrating how concepts like "land-use" or "resource 
exploitation" emerge from a utilitarian solutions-oriented approach, whereas concepts like "resilience" or "sustainability" are embedded in a dilemmas-facing approach, which encompasses problems but frames them within longer-term reasoning and foresight [5].

This is the relevance of heritage at large and of geo-heritage in particular: a cultural understanding of past equilibriums, and disruptions, as compounds of resources, technology, logistics, and sociocultural processes. This has relevant consequences for current global challenges, as in the case of low demographic density territories, i.e., those in which a third of the world population still lives, corresponding to over $95 \%$ of the lithosphere.

\section{Past Strategies between Adaptation and Transformation}

Whereas shared myths and performed rites serve the purpose of consolidating the identity of given human groups and their connection with given territories, also structuring a sense of coherence between the two (i.e., a cultural landscape), heritage, and, namely, tangible heritage, remains as a set of landmarks that organize the perception of territories as anthropic features [6].

Cultural heritage features were originally conceived as witnessing "major achievements" from the past, be those of a local, national, or global scope. A focus on aesthetic and also ethical dimensions related to heritage has been, and in legal documents still remains, the driving concern when heritage management is concerned. However, these features were generated through complex past processes with socio-economic, technological, and environmental dimensions, i.e., they stand as fossil remains from past human strategies, as well as witnessing their trends: adaptive, transformative, or, on occasions, one of denial of contextual challenges. Moreover, heritage from the past recalls the adaptive success of past cultures, but often it also indicates how past cultures and civilizations became extinct, i.e., how they ceased to be sustainable [7]. In contemporary societies, heritage organizes the territories, allowing them to become living cultural landscapes in transformation, acting as the invariants within them: the component which, remaining unchanged, allows for the consideration of a continuity between past, present, and future

The extension of the concept of heritage to whole landscapes, virtually merging the anthropic and the natural features, results from the acceleration of the globalization process: since sustainability is now understood as a total phenomenon, implying all variables at the scale of the planet, the segregation between the cultural and the natural tends to cease. A similar process occurred in the previous main acceleration process in the late 18th and early 19th centuries, and was expressed through the philosophical understanding of humans as part of nature. The current acceleration [8] rendered more evident the role of human agency [9] and thus tends to support the cultural dimension of the understanding of any given natural feature, but in a sense, it is the same merging process, initiated over 200 years ago but interrupted by the first wave of human sciences segregation [10].

For the purpose of the present paper, we consider that the relevance of heritage for understanding the implications of sustainability is based on its role of invariance, i.e., in shaping and defining the approaches of society to global challenges. The concept of geo-park, for instance, is an expression of the merger between the natural and the anthropic, and stands as an example of how science education has also this specific responsibility in contemporary society: to acknowledge the relevance of human cultural different perceptions in understanding reality, but also to demonstrate that within this there is room for science, refusing any form of absolute relativism and anti-scientific reasoning.

Archaeological research, particularly when discussing major transition periods, has long focused on climatic and related environmental changes to assess to what extent these might have triggered, or at least conditioned, human past behavior and adaptations [11]. As an example, research undertaken in the most recent decades has allowed for the tracing of a relation between climatic oscillations, namely, the $8.2 \mathrm{ka}$ dry and cold event during the transition to farming societies [12], but also later dry and warmer oscillations that coincide with relevant farming expansions, or even attempts to relate the rise and decay of the Roman Empire to milder and dryer conditions, or to establish a link between the little ice age and several socio-political episodes in the modern era $[13,14]$. 
While some of humanity's past strategies may be primarily perceived as strategic adaptations to contextual climatic or environmental changes (this is the case for the various Mesolithic groups' strategies, including the first farming attempts following the $8.2 \mathrm{ka}$ event), some others suggest major transformative strategies, such as the emergence of complex proto-state societies in the Mediterranean (following the $5.9 \mathrm{ka}$ dry and warm event which led to the expansion of the Sahara), or the Renaissance and modern era (associated with the little ice age) [15].

The interpretation of the complex relations between human agency and climatic and environmental features is largely open to debate. Nevertheless, at least in the Holocene, it seems that when Bond events follow previous longer milder periods, they tend to precipitate the collapse of previous adaptive and stable strategies. This was the case with the $8.2 \mathrm{ka}$ event after the climatic optimum (disrupting successful Mesolithic and early Neolithic strategies based on abundant resources), the $5.9 \mathrm{ka}$ event after the warmer previous sequence (disrupting the later Neolithic trade systems), the 4.2 ka event (precipitating the collapse of the Egyptian old kingdom and related main state societies), and the 1.4 ka event (condemning later attempts to reconstruct the Roman Empire). Nevertheless, considering the relationship between these episodes and human strategies, it may also be argued that dryer and often cold brief oscillations, while disrupting existing systems, also trigger innovative new strategies, which on occasion become transformative when warmer periods succeed: the Neolithic acceleration after the 7.6 ka oscillation, the Chalcolithic complex farming societies after the 5.9 ka event, the Roman warm period, the medieval warm period, and, perhaps, the current warming period.

In any case, the study and discussion of past climatic events and related human strategies is of fundamental relevance, since this is a debate on past sustainable vs. non-sustainable adaptive responses to contextual changes [16,17], and in this respect the merger of the notions of natural and cultural heritage, embedding the understanding of past climatic events and sustainable human strategies, becomes a major component of contemporary debates on strategies to cope with perceived changes, also helping to distinguishing between events, episodes, and stages or eras, and between specific human systems disruption and the wider collapse of humanity. Reintroducing a solid scientific dimension into the debates prevents one from falling into superficial and non-rigorous statements that block enduring new strategies.

Such a scientific approach, making full use of the contribution of geosciences as a driver to assess contextual modifications and of human sciences to assess patterns of human behavior, also allows one to focus not only on a limited number of immediate challenges (e.g., the large cities) but to consider at all stages the mid- and long-term implications of these challenges and, moreover, their wider territorial contexts (which relate to migrations, re-designing borders, assessing low demographic density territories, etc.) [18].

\section{From Practices to Concepts}

The second most relevant layer or reasoning to consider relates to the understanding of the unity of the human species, which is far from being culturally embedded in the various ethnic traditions but became the main side-product of globalization. The global integration of regional economies from the dawn of triangular trade in modernity and the enhancement of energy supply systems from the industrial revolution and the further acceleration enabled by the global bio-technological nano integrative processes generated a matrix of interdependencies that challenge any attempt to pursue isolated cultural performances and fostered the notion of the human as a common identity across all specific cultures [19]. This, of course, is of major relevance to sustainability, since global sustainability requires coordinated planetary efforts, which can hardly be met by mere occasional agreements that engage identities that do not recognize a more fundamental unity with their counterparts.

However, cultures and cultural traditions remain and prevent any form of unique thinking, i.e., of ideological discourse, to be accepted as equally valid for all, even if using scientific arguments. The notion of sustainable development, for instance, encompasses profound contradictions thast are perceived and faced differently by distinct cultures. For instance, valuing intangible heritage more than sites or monuments is not a universal choice, and while death penalty for criminal polluters 
would be well accepted in some traditions (focused primarily on common good), it would not be welcome in others (focused on individual rights). A similar complex debate occurs concerning energy supply: What should be the planet's short to middle term strategy concerning fossil resources?

Such complex and dividing debates often find better grounds for rational argumentation in low demographic density territories, since despite their distance to main centers and their limited academically qualified human capital, their populations are often closely involved in integrated traditions that allow for a global understanding of phenomena [20]. These territories, often with a higher density of surviving heritage remains, may have better conditions to experiment potential transformative new strategies than larger cities, which need either to continuously fully renovate (destroying heritage) or collapse.

Culturally integrated management of these territories, making full use of heritage as an invariant, is therefore a major driver for transformative practices, which may later be disseminated, should they happen to be sustainable or not. Moreover, ageing and the loss of certain age clusters, while disrupting intergeneration continuity, also fosters the emergence of new syncretic human identities, built on the remaining diversity, a process which is almost impossible to occur in large urban areas in a short time. The management of geological heritage (geoheritage) becomes, in this context, of primeval relevance.

\section{Bridging Heritage and Economics}

The geoheritage concept began to be used in the 1990s and is associated with the question of geodiversity conservation/protection. It includes the multiple aspects of geosphere: particular rocks and minerals, fossils, geological formations, tectonic activities, rare geomorphological aspects, etc. In the last twenty years, many geosites have been classified, both nationally and internationally. Some of these are quite specific and require a fairly high level of scientific knowledge, such as the wonderful geology of Monte Gallo-Sicily [21]. This is why proper disclosure and management is necessary [22].

Geological process and the resulting landscapes are considered integral parts of the ecosystems and may be approached in the same way biodiversity is, as recognized since the Rio de Janeiro 1992 summit.

The slow geological path is lately altered by human evolution. Indeed, through the Quaternary geological period (last 2.58 million years), geological processes and human activities became growingly interconnected. While the Quaternary geological phenomena (particularly glaciations, volcanism, or neotectonics) have conditioned human evolution, also, anthropic activity generated changes in the biosphere and the geosphere [23]. It is in this context that the term Anthropocene started to be used, even if temporal limits are still under discussion, including the proposal to coincide with the Quaternary (which would be a way of resuming the abandoned concept of Anthropozoic), to the identification of different human transformative processes, such as the dawn of agriculture, the industrial revolution, or the year 1950 [24]. While from a long-term geological perspective the debate may be unsolvable, both from the perspective of heritage and archaeological and anthropological studies, only the first option, making the Quaternary coincide with the Anthropocene, seems pertinent, allowing for the assessment of a longer period that encompasses the multiple variations of human adaptive strategies and their sustainability. Human adaptations to different physical phenomena, global meteorological patterns, and oscillations in global sea level, as well as our understanding of how natural resources have been used in the past, provide us with keyentries to reading socio-cultural processes and the resilience of human populations. In this context, the geological heritage and anthropic dimension overlap to constitute a single heritage, albeit with its different specificities, as the use of flint, for example, exemplifies, from the lower Paleolithic communities to its present use in new technologies for contemporary economies.

Such an understanding of the heritage dimension of geological features has, besides its educational and technological implications, major relevance for tourism too. International tourist arrivals grew by a remarkable $7 \%$ in 2017, to reach a total of 1322 million, according to the latest UNWTO World Tourism Barometer. This strong momentum is expected to continue in 2018 at a rate 
of $4-5 \%$, as shown by the report of UNWTO [25]. The touristic system creates links between offerdemand operators. Each touristic system becomes more dynamic and generates more profits when the cultural assets are integrated in tourist activities. Thus, the management share is the key for the good work of all the territorial agents [26]. While tourism sells natural and cultural products rooted in heritage and contemporary creativity, the adaptation of several mechanisms for safeguarding natural and cultural heritage is necessary, as UNESCO stresses. The geotourism product is complex, special, and demanding, in terms of its global shared management, from preservation to the responsibility for the final results, including investments, revenues, and profits. Geotourism is part of cultural tourism, and in Portugal one can access the "Geological Heritage of Portugal" website and discover many possibilities to geo-sites virtual visitation and real tours planning [27]. The value assigned to geological heritage is a cultural value, which generates cultural landscapes, i.e., places with vocation for welcoming visitors. As written by A. Chen et al. [28], the extensive and close relationship between tourism and geology is not limited to natural landscapes, because geological contents are also found in many research topics of cultural landscapes. For example, the selection and processing of varied stone materials used in some historical buildings, commemorative archways, monuments, towers, and columns, as well as landscaping pavilions, bridges, corridors, and gardens depended on outcrops, geological conditions, and physical and chemical properties of different rocks, and was therefore closely related to technological petrology and engineering geology of applied geology; besides, in the vicissitudes of thousands of years, some cultural relics and historical sites recorded and stored the traces of some geological processes, bearing witness to crustal movements and geological processes.

The tourist can see and learn «in situ» the entire described universe and interact with the landscape, making a contribution to the conservation of all these places [29]. This is the best integration that tourism and scientific geology can allow for: a better relationship between people and nature, with economics being a component of the process.

\section{New Tools for New Challenges}

In the context of global challenges related to sustainability, conservation is a key-word. Geoconservation is related to new social responsibility towards the use of Earth resources, namely, the geological elements with exceptional scientific, educational, touristic, or cultural valuegeological heritage [30]. Different countries and/or regions around the world, by displaying very different social conditions, legislation, and history linked to nature management, may take care or not of their geological heritage [31]. Geoparks are a relevant and innovative tool with which to face these challenges.

The European Geoparks Network (EGN) was an informal structure founded in 2000 that aims to establish a collaborative network to promote the protection of the European geological heritage through geoparks [32]. Geoparks are living, working landscapes with exceptional geological heritage in which science and local communities engage in a mutually beneficial way [33]. They represent innovative ways to foster economic sustainable development of local communities through the promotion of geotourism and education.

The EGN experienced remarkable success, which led to the establishment of a "Global Network of National Geological Parks (Geoparks) seeking UNESCO's assistance" [32] then to the Global Geoparks Network (GGN), constituted in 2004 under the auspices of UNESCO [34]; and, finally, to the UNESCO Global Geoparks approved in 2015 within the International Geoscience and Geoparks Programme [35].

At present, there are 140 UNESCO Global Geoparks distributed by 38 countries in all continents (Figure 1). By connecting nature conservation, land-use planning, and sustainable development of local communities, geoparks represent a sustainable strategy for the development of territories displaying exceptional geological heritage that can be adapted to the cultural context, as well as to different social and economic contexts [36]. As bottom-up initiatives that require community involvement and the need to work across other disciplines besides earth sciences, geoparks model 
can inspire other strategies for targeted local projects with global impact, thus meeting the current challenges of building bridges between global thinking and local actions [37].

\section{Distribution of GGN Members}

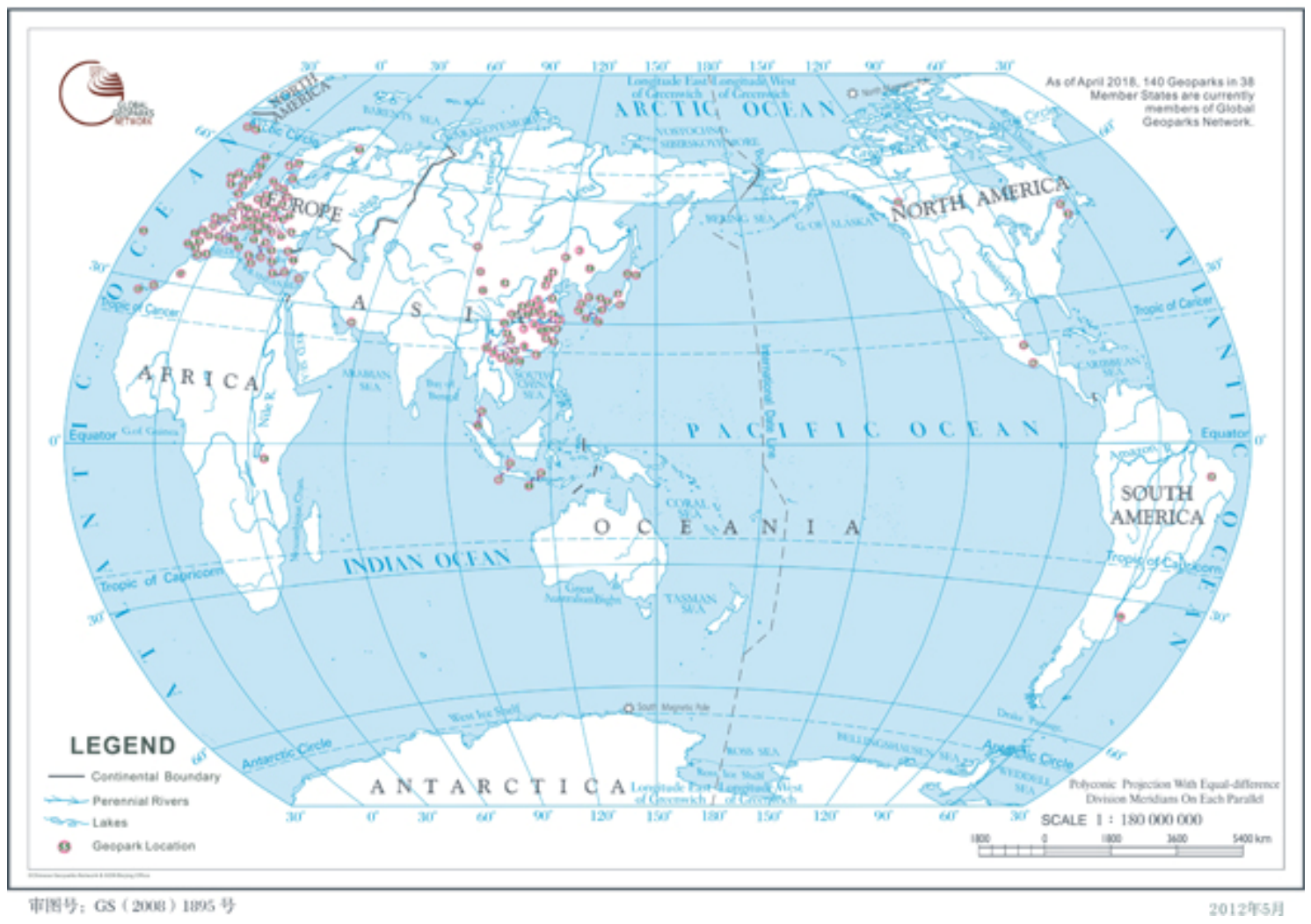

Figure 1. Worldwide distribution of the 140 UNESCO Global Geoparks as of April 2018 [38].

\section{Conclusions}

While most public policies are oriented towards the cities and areas of major economic intensification and interaction, most territories remain with low demographic densities. To a large extent, and despite human uneven distribution and growing concentration, global sustainability will be challenged and to a large extent decided in these territories, which experience unequal access to acceptable standards of quality and growing economic, social, and environmental stress, in terms of employment, entrepreneurial opportunities, logistics, or cultural experiments. Countries also experience global consequences of this lack of attention: extensive fires in the summer with severe socioeconomic and environmental consequences; terrorism, smuggling, and even slave routes hiding in such areas; growing xenophobia and segregationist movements; and weakening of the rule of law in terms of environment protection.

While infrastructures may exist in many of these non-megalopolis areas, they proved to be necessary but insufficient to address problems. Investing in alternative approaches should be the obvious choice to make, but despite several local experiences, no global reasoning exists. One of the difficulties resides in the dispersal of humans and a lower level of critical mass in many contexts. However, most preserved and visitable geological heritage is located precisely in those territories, and it attracts visitors who predominantly come from the high-density and high-critical mass areas. Geoheritage may, for this reason, be used as not only a reminder of the relevance of diversity for a sustainable future but as a driver connecting tlarge cities (where most human actions take place) and low-density territories (where most geo-transformations take place), raising awareness through connecting nature and culture, fostering an understanding of past and present uses of such features, and creating value through their preservation. 
In the last decade, efforts to recognize the relevance of human agency when discussing sustainability [3], to implement new models of integrated landscape management [39] to conceive new processes of fostering global understanding of current challenges [37], to enhance the scope of sustainability science [40], or to bridge sciences and humanities [18], all move in the same integrative direction.

The challenges for the low demographic density territories are specific, when compared to major cities, but they are not different, since current sustainability challenges are global and integrated. They require, though, specific measures, tailor made, and mechanisms to better integrate them as parts of a shared matrix. Geoheritage may be a driver for such integration.

Author Contributions: Conceptualization and discussion, L.O. and M.H.H.; geoparks and geo-heritage identification and management, M.H.H. and P.R.; economics and tourism, P.R. and L.M.F.

Funding: This research was funded by the Portuguese Foundation for Science and Technology, grant number UID/Multi/00073/2013.

Acknowledgments: The authors wish to thank their colleagues in the Geosciences Centre of Coimbra University (www.uc.pt/fctuc/ID/Geo) and its member institutions (UC, IPT, ITM, and UTAD) for all the discussions and networking that fed this paper. For the same reason, they wish to thank the partners in the International Association for Cultural Integrated Landscape management (www.apheleiaproject.org).

Conflicts of Interest: The authors declare no conflict of interest. The founding sponsors had no role in the design of the study; in the collection, analyses, or interpretation of data; in the writing of the manuscript; or in the decision to publish the results.

\section{References}

1. Rössler, M. World Heritage for Sustainable Development in Africa; UNESCO: Paris, France, 2018; ISBN 978-923-000045-5.

2. Levis, C.; Costa, F.R.C.; Bongers, F.; Peña-Claros, M.; Clement, C.R.; Junqueira, A.B.; Neves, E.G.; Tamanaha, E.K.; Figueiredo, F.O.G.; Salomão, R.P.; et al. Persistent effects of pre-Columbian plant domestication on Amazonian forest composition. Science 2017, 355, 925-931, doi:10.1126/science.aal0157.

3. United Nations. The Future We Want: Outcome Document of the United Nations Conference on Sustainable Development; UN: Rio de Janeiro, Brazil, 2012. Available online: https://sustainabledevelopment.un.org/content/documents/733FutureWeWant.pdf-c (accessed on 10 May 2018).

4. Scheunemann, I.; Oosterbeek, L. (Eds.). A New Paradigm of Sustainability: Theory and Praxis of Integrated Landscape Management; IBIO: Rio de Janeiro, Brazil, 2012; ISBN 978-85-60840-11-3.

5. Oosterbeek, L.; Quagliuolo, M.; Caron, L. (Eds.). Sustainability Dilemmas. Transdisciplinary Contributions to Integrated Cultural Landscape Management; Série ARKEOS; ITM: Mação, Portugal, 2016; Volume 38-39, ISBN 978-989-99131-2-7.

6. Oosterbeek, L.; Pollice, F. Cultural Heritage and Local Development. Local Communities through Heritage Awareness and Global Understanding; Appendix to Territori Della Cultura n. 18; Centro Universitario Europeo per I Benu Culturali: Ravello, Italy, 2014; ISSN 2280-9376.

7. Flenley, J.; Bahn, P. The Enigmas of Easter Island; University Press: Oxford, UK, 2003; ISBN 978-01-92803-40-5.

8. Santos, F.D. Que Futuro? Ciência, Tecnologia, Desenvolvimento e Ambiente; Gradiva: Lisboa, Portugal, 2007; ISBN 978-989-616-215-3.

9. Meusburger, P.; Werlen, B. Knowledge, Action, and Space: An Introduction; Elsevier: Cham, Switzerland, 2017; ISBN 978-3-319-44588-5.

10. Oosterbeek, L. Is There a Role for the Humanities in Face of the Global Warming and Social Crisis? J. Iber. Archaeol. 2011, 14, 97-103, ISSN 0874-2677.

11. Scarre, C. The Human Past. World Prehistory \& the Development of Human Societies, 4th ed.; Thames \& Hudson: London, UK, 2018; ISBN 978-050-02933-5-5.

12. Budja, M. The 8200 calBP 'climate event' and the process of neolithisation in south-eastern Europe. Doc. Praehist. 2007, XXXIV, 191-201, ISSN 1408-967X. 
13. Kaniewski, D.; Paulissen, E.; Van Campo, E.; Weiss, H. Late second-early first millennium BC abrupt climate changes in coastal Syria and their possible significance for the history of the Eastern Mediterranean. Quat. Res. 2010, 74, 207-215, ISSN 0033-5894.

14. Weis, B. The decline of Late Bronze Age civilization as a possible response to climatic change. Clim. Chang. 1982, 4, 173-198, doi:10.1007/BF00140254.

15. Pfister, C.; Brazdil, R. Social vulnerability to climate in the "Little Ice Age": An example from Central Europe in the early 1770s. Clim. Past 2006, 2, 115-129, doi:10.5194/cp-2-115-2006.

16. Bond, G.; Kromer, B.; Beer, J.; Muscheler, R.; Evans, M.N.; Showers, W.; Hoffmann, S.; Lotti-Bond, R.; Hajdas, I.; Bonani, G. Persistent Solar Influence on North Atlantic Climate during the Holocene. Science 2001, 294, 2130-2136. ISSN 1095-9203.

17. Obrochta, S.P.; Yokoyama, Y.; Morén, J.; Crowley, T.J. Conversion of GISP2-based sediment core age models to the GICC05 extended chronology. Quat. Geochronol. 2014, 20, 1-7, doi:10.1016/j.quageo.2013.09.001.

18. Crowley, J.; Oosterbeek, L.; CIPSH-UNESCO. Challenges and Responsibilities for a Planet in Transition. Proceedings of the World Humanities Conference, Liège, Belgium, 6-11 August 2017; CIPSH-UNESCO: Paris, France; ITM: Mação, Portugal, 2017; ISBN 978-989-99131-6-5.

19. Oosterbeek, L. Becoming Human. New approaches for uncertain times. In: Sustainability Dilemmas. Transdisciplinary Contributions to Integrated Cultural Landscape Management; Série ARKEOS; Oosterbeek, L., Quagliuolo, M., Caron, L., Eds.; ITM: Mação, Portugal, 2016; Volume 38-39, pp. 85-107, ISBN 978-98999131-2-7.

20. Scarborough, V.L.; Chase, A.F.; Chase, D.Z. Low Density Urbanism, Sustainability, and IHOPE- Maya: Can the Past Provide more than History? UGEC Viewp. 2012, 8, 20-24.

21. Basilone, L.; Di Maggio, C. Geology of Monte Gallo (Palermo Mts, NW Sicily). J. Maps 2016, doi:10.1080/17445647.2015.1124716.

22. Henriques, M.H. Geosites, Management of. In Encyclopedia of Mineral and Energy Policy; Tiess, G., Majumder, T., Cameron, P., Eds.; Springer: Berlin, German, 2015.

23. Kozlowski, S. The concept and scope of geodiversity. Prz. Geol. 2004, 52, 833-837, ISSN 0033-2151.

24. Zalasiewicz, J.; Waters, C.; Summerhayes, C.P.; Wolfe, A.P.; Barnosky, A.D.; Cearreta, A.;Crutzen, P.; Ellis, E.; Fairchild, I.J.; Gałuszka, A.; et al. The Working Group on the Anthropocene: Summary of evidence and interim recommendations. Anthropocene 2017, 19, 55-60, doi:10.1016/j.ancene.2017.09.001.

25. UNWTO. 2017-International Tourism Results: The Highest in Seven Years, PR No. 18003, 15 January 2018. Available online: http://media.unwto.org/press-release/2018-01-15/2017-international-tourism-resultshighest-seven-years (accessed on 14 May 2018).

26. ICOMOS. INTERNATIONAL CULTURAL TOURISM CHARTER-Managing Tourism at Places of Heritage Significance, 1999. Available online: https://www.icomos.org/charters/tourism_e.pdf (accessed on 14 May 2018).

27. Universidade do Minho. Património Geológico de Portugal-Inventário de Geossítios de Relevância Nacional, Departamento de Ciências da Terra, 2014. Available online: http://geossitios.progeo.pt/index.php (accessed on 14 May 2018).

28. Chen, A.; Lu, Y.; Young, C. The Principles of Geotourism; Springer: Berlin/Heidelberg, German, 2015; ISBN 978-3-662-46697-1.

29. ICOMOS. The Florence Declaration on Heritage and Landscape as Human Values, 2014. Available online: https://www.icomos.org/images/DOCUMENTS/Secretariat/2015/GA_2014_results/GA2014_Symposium_ FlorenceDeclaration_EN_final_20150318.pdf (accessed on 14 May 2018).

30. Henriques, M.H.; Reis, R.P.; Brilha, J.; Mota, T. Geoconservation as an Emerging Geoscience. Geoheritage 2011, 3, 117-128, doi 10.1007/s12371-011-0039-8.

31. Henriques, M.H. Geoconservation policy. In Encyclopedia of Mineral and Energy Policy; Tiess, G., Majumder, T., Cameron, P., Eds.; Springer: Berlin/Heidelberg, Germany, 2014; pp. 1-4, ISBN 978-3-642-40871-7.

32. Zouros, N. The European Geoparks Network: Geological heritage protection and local development. Episodes 2004, 27, 165-171, doi:10.18814/epiiugs/2016/v39i4/103894.

33. UNESCO. Statutes of the International Geoscience and Geoparks Programme and Operational Guidelines for UNESCO Global Geoparks; UNESCO: Paris, France, 2015. Available online: www.globalgeopark.org/UploadFiles/2012_9_6/IGGP_EN_Statutes_and_Guidelines.pdf (accessed on 14 May 2018). 
34. Eder, W.; Patzak, M. Geoparks-Geological attractions: A tool for public education, recreation and sustainable economic development. Episodes 2004, 27, 162-164, ISSN 2586-1298.

35. UNESCO. UNESCO Global Geoparks; UNESCO: Paris, France, 2018. Available online: www.unesco.org/new/en/natural-sciences/environment/earth-sciences/unesco-global-geoparks/ (accessed on 14 May 2018).

36. Henriques, M.H.; Brilha, J. UNESCO Global Geoparks: A strategy towards global understanding and sustainability. Episodes 2017, 40, 349-355, doi:10.18814/epiiugs/2017/v40i4/017036.

37. Werlen, B.; Osterbeek, L.; Henriques, M.H. 2016 International year of global understanding: Building bridges between global thinking and local actions. Episodes 2016, 39, 604-611, doi:10.18814/epiiugs/2016/v39i4/103894.

38. GGN. Distribution of Global Geoparks Network Members, 2018. Available online: www.globalgeopark.org/homepageaux/tupai/6513.htm (accessed on 14 May 2018).

39. Oosterbeek, L. Cultural Integrated Landscape Management: A Humanities Perspective; Série ARKEOS; Instituto Terra e Memória: Mação, Portugal, 2017; Volume 43, ISBN 978-989-99131-7-2.

40. UNESCO. Guidelines on Sustainability Science in Research and Education. Available online: https://en.unesco.org/sites/default/files/guidelines_sus_f_0.pdf (accessed on 14 May 2018).

(C) 2018 by the authors. Licensee MDPI, Basel, Switzerland. This article is an open access article distributed under the terms and conditions of the Creative Commons Attribution (CC BY) license (http://creativecommons.org/licenses/by/4.0/). 